\title{
MicroRNAs as Potential Markers Involved in Erythroid Differentiation: A Systematic Literature Review
}

\author{
Chunmei Guo ${ }^{1}$, Xinli Li ${ }^{1}$, Shuqing Liu ${ }^{2}$, Mingzhong Sun ${ }^{1,}$ * \\ ${ }^{1}$ Department of Biotechnology, College of Basic Medical Sciences, Dalian Medical University, Dalian, China \\ ${ }^{2}$ Department of Biochemistry, College of Basic Medical Sciences, Dalian Medical University, Dalian, China
}

Email address:

smzlsq@163.com (Mingzhong Sun)

${ }^{*}$ Corresponding author

\section{To cite this article:}

Chunmei Guo, Xinli Li, Shuqing Liu, Mingzhong Sun. MicroRNAs as Potential Markers Involved in Erythroid Differentiation: A Systematic Literature Review. Science Journal of Clinical Medicine. Vol. 10, No. 2, 2021, pp. 16-29. doi: 10.11648/j.sjcm.20211002.11

Received: April 6, 2021; Accepted: April 19, 2021; Published: April 23, 2021

\begin{abstract}
As a family of small non-coding RNAs, microRNAs (miRNAs) negatively modulate gene expression via directly targeting mRNAs in a sequence-specific pattern. Accumulated evidences have indicated that miRNAs involved in erythroid differentiation. Some experimental systems used for study the association of miRNAs with erythroid differentiation: 1) embryonic stem cells (hESCs) forced to erythropoiesis, 2) hematopoietic progenitor cells and erythroid-like cell lines induced to erythropoiesis by hypoxia and chemical substances, 3) and in vivo mice, zebrafish embryo systems. Based on the literatures, miR-451, miR-144, miR-486, miR-126-3p, miR-107, miR-199b-5p, miR-362, miR-188, miR-210, miR-125a, miR-146b, miR-22, miR-23a / miR-27a / miR-24, miR-16-2, miR-34a exhibit promotion role in erythropoiesis, while, miR-218, miR-320a, miR-221 / 222, miR-433, miR-200a, miR-223, miR-150, miR-34a-5p, miR-124, miR-Let-7d, miR-376a, miR-155, miR-126 / 126*, miR-103, miR-15a, miR-30a-5p, miR-26a-5p, miR-669m, miR-9 show suppression role in erythropoiesis. Nonetheless, the clear functional role of miR-24 is controversial in erythropoiesis. This article summarized the relationships between miRNAs and erythroid differentiation as well as potential target genes and action mechanisms. These discovered erythroid associated miRNAs stand for the starting point to develop novel approaches for miRNA treatment, miRNAs to be used as novel potential biomarker and target for diagnosis, therapeutics, prognosis of certain blood diseases, leading to promising prospects in blood diseases therapeutics.
\end{abstract}

Keywords: miRNAs, Erythroid Differentiation, Target Genes

\section{Introduction}

microRNAs (miRNAs) are about 22 nucleotides endogenous small non-coding RNAs that negatively modulate gene expression by directly inhibiting protein translation or degrading mRNA via directly binding to the $3^{\prime}$-UTR of targeted mRNAs $[1,2]$. A miRNA can bind to one or more mRNAs, about $30 \%$ of protein coding genes are known widely modulated by miRNAs. Its involved in cell differentiation, development, progression, apoptosis, proliferation, metastasis, chemoresistance and metabolism of crucial biological processes [3]. Specially, miRNAs are also functioning as tumor inhibitor or promoter in tumorigenesis $[4,5]$. Meanwhile, miRNAs play critical roles in accurate modulation regulation of stem cells start differentiating process which is vital for prevention and therapy of hematologic disorders [6]. Increasing evidences demonstrated miRNAs can modulate hematopoiesis and a number of miRNAs are specific for hematopoietic lineages. miRNA can potentially be clinical diagnostic and therapy biomarker because it has a high stability to describe biological change [7].

Hematopoiesis is a highly and precisely regulated multistage process which erythroid cells, lymphocytes and myeloid cells are originated from pluripotent stem cell [8]. Normal erythropoiesis produces about $10^{11}$ new red blood cells (RBCs) in adult human every day through the commitment of hematopoietic stem cells into erythroid progenitors, subsequently differentiate into mature RBCs, RBCs are responsible for providing oxygen to the growing fetal, embryonic, adult tissues, maintaining blood viscosity 
and offering the shear stress which required for vascular remodeling and development [9]. The individual is in danger for serious pathological states containing thrombocytopenia and anemia when this normal erythropoiesis process is destroyed. On account of this rapid turnover in circulating blood cells, the hematopoietic system is poised to continuously supplement these lineages via differentiation, proliferation and maturation of immature progenitor populations.

Erythropoiesis is a multi-step cellular process by which a primitive multipotent hematopoietic stem cell (HSC) experiences a series of differentiations resulting in production of erythroid lineage, undergoing erythroid progenitors (colony-forming unit erythroid [CFU-E] and burst-forming unit erythroid [BFU-E]), normoblasts, proerythroblasts, early basophilic erythroblasts, late basophilic erythroblasts, polychromatic erythroblasts, orthochromatic erythroblasts, reticulocytes, ultimately differentiating to mature erythrocytes The dynamic process is mediated by the balance of intrinsic and extrinsic factors, containing transcription factors, growth factors and miRNAs [10]. miRNAs are greatly associated with erythroid differentiation, regulating maturation of erythroid cells and transcription of globin genes [11].

A variety of testing systems can be applied to study the association of miRNAs with erythropoiesis, containing human embryonic stem cells (hESCs) forced to erythropoiesis, erythroid-like cell lines K562, TF-1, HEL, MEL, UT-7, KCL-22, MDS-L cells induced to erythropoiesis by hypoxia and chemical substances, erythropoietin (EPO)-induced
CD34+ cells, CD133+ undergo erythroid differentiation which from hematological disease patients or normal healthy subjects, and in vivo systems, for example mice, zebrafish embryo.

The primary-miRNA (pri-miRNA) is synthesised in nucleus by RNA polymerase II, DiGeorge syndrome critical region 8 (DGCRB) and Drosha to cleave the pri-miRNAs, releasing precursor miRNA (pre-miRNA), which is carried to cytoplasm by GTP-bound Ran (RanGTP) and exportin-5 [12]. Following dicer cleaved pre-miRNA into about 22 nucleotide functional mature miRNA, then mature miRNA assembled into the Argonaute2 (Ago2) to form RISC [13]. Subsequently, the miRNA regulated erythroid differentiation by inhibiting translation via directly binding to the 3'-UTR of targeted mRNA (Figure 1). To date, dozens of miRNAs have been identified to be associated with erythroid differentiation, these discovered erythroid associated-miRNAs on behalf of the starting point to develop novel approaches for miRNA treatment, based on miRNA silencing or miRNA replacement. This article summarized the relationships between miRNAs and erythroid differentiation, as well as potential action mechanisms in recent years. The study obtained on it has led to a new interest in underlying role and mechanism of miRNAs dysexpression in erythroid differentiation, which might potentially offer new insight of miRNAs deregulation in erythroid differentiation study. We believe that understanding the roles of miRNAs involved in erythroid differentiation would offer new viewpoint for developing novel diagnostic markers and treatment reagents and of certain blood diseases.

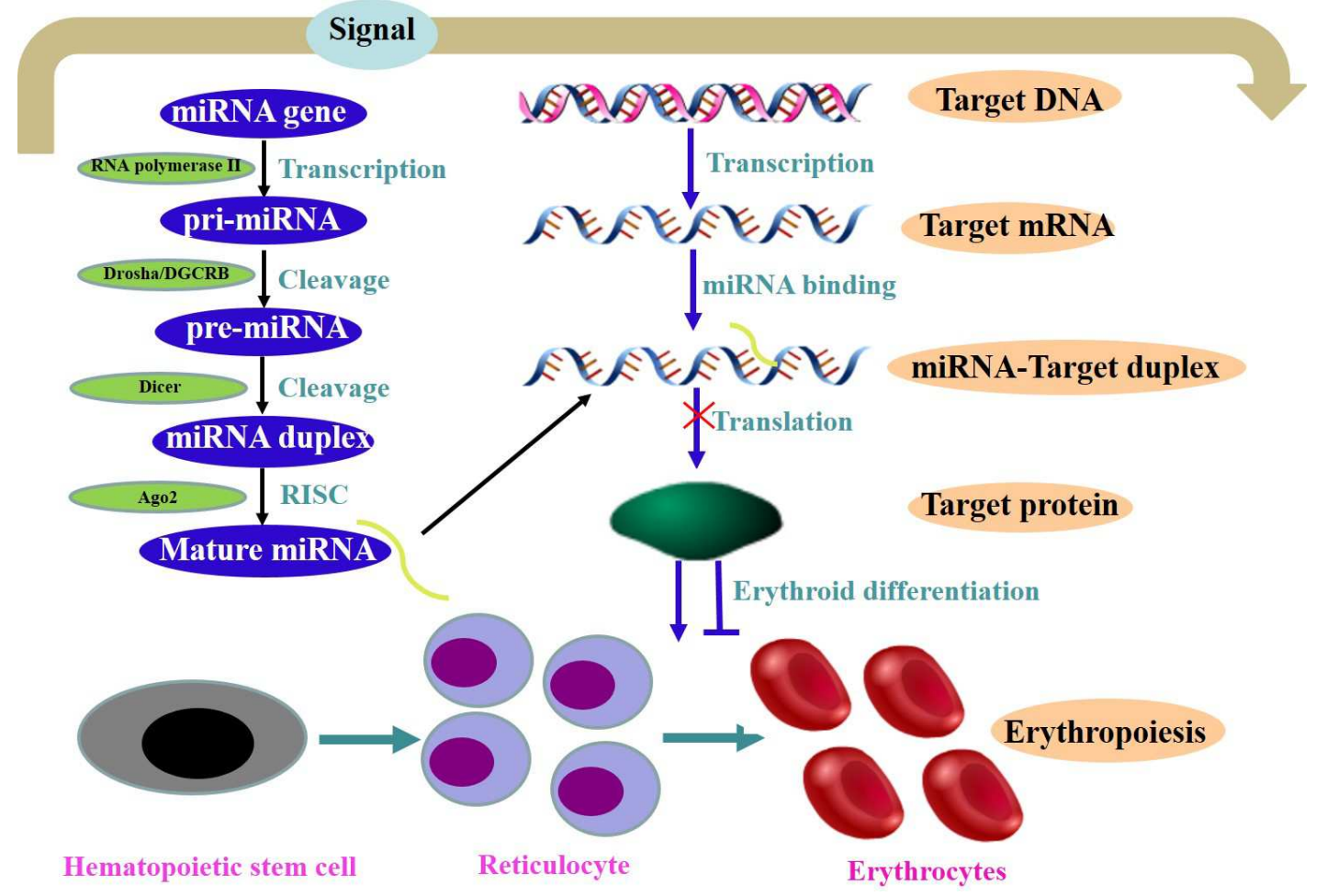

Figure 1. The biosynthesis of miRNA and its regulatory mechanism on erythroid differentiation. The pri-miRNA is synthesised in nucleus by RNA polymerase II, then pri-miRNAs are cleaved by Drosha and DGCRB, and releasing pre-miRNA, which is carried to cytoplasm by exportin-5 and Ran GTP. Once the pre-miRNA reaches the cytoplasm, Dicer cleaves it into nearly a 22 nucleotide long functional mature double-stranded miRNA, which then assembles into the Ago2 protein to form RISC. Following the miRNA regulates erythroid differentiation by suppressing protein translation via binding to the 3'-UTR of targeted mRNA. 
Table 1. miRNAs promoted erythroid differentiation.

\begin{tabular}{|c|c|c|c|c|}
\hline miRNA & $\begin{array}{l}\text { Experimental } \\
\text { model system }\end{array}$ & Biological effect & Target and mechanism & Ref \\
\hline $\begin{array}{l}\operatorname{miR}-144 / \\
\operatorname{miR}-451\end{array}$ & $\begin{array}{l}\text { K562, CD34+, } \\
\text { CD133+, TF1, } \\
\text { MEL, zebrafish, } \\
\text { mice }\end{array}$ & $\begin{array}{l}\text { miR-451 expression increased during erythroid differentiation } \\
\text { of purified normal or thalassemic human erythroid progenitors } \\
\text { and EPO-induced TF1, hemin-induced K562, DMSO-induced } \\
\text { MEL cells; miR-451 overexpressed in red blood cells; Mice and } \\
\text { zebrafish deficient for the miR-144 / } 451 \text { cluster resulting in } \\
\text { erythroid hyperplasia, splenomegaly and mild anemia; } \\
\text { miR-144 / miR-451 promoted EPO-, hemin-, DMSO-induced } \\
\text { erythroid differentiation of TF1, K562 and MEL cells; miR-451 } \\
\text { induced erythroid differentiation and maturation of CD133+ } \\
\text { cell and zebrafish; miRNA-451a attenuated the inhibitory } \\
\text { effects on erythroid diferentiation of HQ-treated K562 cell }\end{array}$ & $\begin{array}{l}\text { miR-451 protected against erythroid } \\
\text { oxidant stress via regulating nuclear } \\
\text { localization and activity of FoxO3 by } \\
\text { repressing } 14-3-3 \zeta \text {; A novel RUNX1 / } \\
\text { ETO-miR144 / } 451-\mathrm{RAB} 14 \text { axis } \\
\text { contributed to erythroid differentiation; } \\
\text { miR-451 promoted erythroid maturation } \\
\text { by targeting GATA2 }\end{array}$ & [14-24] \\
\hline $\operatorname{miR}-126-3 p$ & CD34+ & miR-126-3p expression lower in HQ-treated CD34+ cell & & [21] \\
\hline miR-486 & $\begin{array}{l}\mathrm{K} 562, \mathrm{CD} 34+, \\
\mathrm{TF}-1, \text { mice }\end{array}$ & $\begin{array}{l}\text { upregulated during EPO-, GM-, hypoxia-induced erythroid } \\
\text { differentiation of CD34+ and TF-1 cells; miR-486 } \\
\text { overexpression promoted erythroid differentiation of K562, } \\
\text { CD34+ and TF-1 cell; miR-486 upregulated in CML compared } \\
\text { with normal CD34+ cells; miRNA-486 negatively correlated } \\
\text { with the concentration of benzene inhalation on erythroid } \\
\text { toxicity of C57BL / } 6 \mathrm{~J} \text { mice }\end{array}$ & $\begin{array}{l}\text { miR- } 486 \text { regulated the proliferation and } \\
\text { erythroid differentiation through } \\
\text { targeting Sirt1 }\end{array}$ & $\begin{array}{l}{[21} \\
25-27]\end{array}$ \\
\hline miR-210 & $\begin{array}{l}\text { UT-7, TER-119, } \\
\text { K562, CD34+ }\end{array}$ & $\begin{array}{l}\text { miR-210 highly expressed in UT-7 / EPO compared to UT-7 / } \\
\text { GM cell; miR-210 knockdown led to UT-7 / EPO cell } \\
\text { apoptosis; miR-210 expression higher in TER-119-positive } \\
\text { cells than in TER-119-negative cells; miR-210 upregulated } \\
\text { during MTH-, hemin- and EPO-induced erythroid } \\
\text { differentiation of UT-7, K562 and CD34+ cells; miR-210 } \\
\text { promoted erythroid differentiation of K562 and CD34+ cells }\end{array}$ & $\begin{array}{l}\text { PLC } \beta 1 \text { inhibited MTH-induced } \\
\text { erythroid differentiation by inhibiting } \\
\text { miR-210 expression }\end{array}$ & {$[28,32]$} \\
\hline $\begin{array}{l}\operatorname{miR}-188 \\
\operatorname{miR}-362\end{array}$ & UT-7 & $\begin{array}{l}\text { miR-188 and miR-362 highly expressed in UT-7 / EPO } \\
\text { compared to UT-7 / GM cell; miR-188 and miR-362 } \\
\text { upregulated in UT-7 cells upon stimulation with EPO }\end{array}$ & & {$[28]$} \\
\hline miR-107 & K562, KCL-22 & $\begin{array}{l}\text { miR-107 promoted sodium butyrate-induced K562 and } \\
\text { KCL-22 cells erythroid differentiation, having no effect on } \\
\text { proliferation }\end{array}$ & $\begin{array}{l}\text { miR-107 promoted erythroid } \\
\text { differentiation by targeting Cacna } 2 \mathrm{~d} 1\end{array}$ & {$[33]$} \\
\hline $\operatorname{miR}-181 \mathrm{a}$ & K562 & $\begin{array}{l}\text { miR-181a reduced in CML patient and K562 cell; miR-181a } \\
\text { promoted hemin-induced erythroid differentiation of K562 cell }\end{array}$ & & [34] \\
\hline miR-199b-5p & K562 & $\begin{array}{l}\text { miR-199b-5p upregulated during hemin-induced erythropoiesis } \\
\text { of K562 cell; miR-199b-5p overexpression forced erythroid } \\
\text { differentiation of K562 cell }\end{array}$ & $\begin{array}{l}\text { A novel GATA-1 / } \\
\text { NF-E2-miR-199b-5p-c-Kit axis } \\
\text { contributed to erythroid differentiation }\end{array}$ & {$[35]$} \\
\hline $\operatorname{miR}-125 \mathrm{a}$ & $\begin{array}{l}\text { K562, CD34+, } \\
\text { MDS-L }\end{array}$ & $\begin{array}{l}\text { miR-125a overexpressed in BM CD34+ cells from MDS } \\
\text { patients compared to BM CD34+ cells from healthy donors; } \\
\text { miR-125a overexpression inhibited Ara-C-induced K562 and } \\
\text { MyD88-induced MDS-L cells erythroid differentiation }\end{array}$ & & {$[36]$} \\
\hline $\operatorname{miR}-146 b$ & K562, CD34+ & $\begin{array}{l}\text { miR-146b upregulated during hemin-induced K562 and } \\
\text { EPO-induced CD34+ cells erythroid differentiation; miR-146b } \\
\text { overexpression / knockdown promoted / inhibited erythroid } \\
\text { differentiation of K562 and CD34+ cells }\end{array}$ & $\begin{array}{l}\text { miR-146b, transcriptionally activated by } \\
\text { GATA-1, promoted erythroid } \\
\text { differentiation via regulating the } \\
\text { PDGFRA / JNK / JUN / HEY1 pathway }\end{array}$ & {$[37]$} \\
\hline miR-22 & mice & $\begin{array}{l}\text { miR-22 knockout impaired erythropoiesis and enhanced } \\
\text { megakaryopoiesis in mice }\end{array}$ & & {$[38]$} \\
\hline $\begin{array}{l}\operatorname{miR}-23 a / \\
\operatorname{miR}-27 a / \\
\operatorname{miR}-24\end{array}$ & $\begin{array}{l}\mathrm{K} 562, \mathrm{CD} 34+ \\
\text { zebrafish, mice }\end{array}$ & $\begin{array}{l}\text { miR-23a upregulated during hemin-induced K562 and } \\
\text { EPO-induced CD34+ cells erythroid differentiation; miR-23a } \\
\text { promoted erythroid differentiation of K562 and CD34+ cells; } \\
\text { miR-23a / miR-27a / miR-24 suppression of miR-23a blocked } \\
\text { erythroid differentiation in zebrafish and overexpression of } \\
\text { miR-23a enhanced mature erythroid populations in mice } \\
\text { miR-16-2 overexpression / knockdown stimulated / inhibited } \\
\text { erythroid cell proliferation and maturation; miR-16-2 inhibited } \\
\text { erythropoiesis in xenograft mice }\end{array}$ & $\begin{array}{l}\text { A novel GATA-1-miR-23a-SHP2 axis } \\
\text { and positive feedback loop } \\
\text { KLF3-miR-23a contributed to erythroid } \\
\text { differentiation; A regulatory circuit } \\
\text { comprising GATA1 / } 2 \text { switch and } \\
\text { miR-27a / } 24 \text { promotes erythropoiesis }\end{array}$ & [39-42] \\
\hline miR-34a & K562 & $\begin{array}{l}\text { miR-34a overexpression promoted hemin-induced erythroid } \\
\text { differentiation of K562 cell }\end{array}$ & $\begin{array}{l}\text { miR-34a promoted erythroid } \\
\text { differentiation through regulated } \\
\gamma \text {-globin expression by binding to STAT3 }\end{array}$ & {$[44]$} \\
\hline
\end{tabular}




\section{2. miRNAs Promoted Erythroid Differentiation}

An overview of research progress so far indicated that some miRNAs were positively correlated with erythroid differentiation, the overexpression of miR-144, miR-451, miR-486, miR-126-3p, miR-107, miR-24, miR-199b-5p, miR-188, miR-362, miR-210, miR-125a, miR-146b, miR-22, miR-23a / miR-27a / miR-24, miR-34a, miR-16-2 promoted erythroid differentiation, as summarized in Table 1. These miRNAs have been recommended as potential suitable treatment targets for blood-related disorders.

\section{1. $\mathrm{miR}-144 / \mathrm{miR}-451$}

miR-144 / miR-451 are co-transcribed miRNAs, many literatures reported miR-144 / 451 were closely related with erythroid differentiation. miR-451 was upregulated 270 -fold during erythropoiesis of purified normal human erythroid progenitors, and the expression level of miR-451 in red blood cells was approximately 10000-fold higher than in granulocytes, suggesting miR-451 was key molecule for normal erythropoiesis [14]. Meanwhile, miR-451 was also increased during thalassemic peripheral blood CD34+ cell erythroid differentiation of erythroid progenitors [15]. In contrast, miR-451 showed no transient up-regulation in erythroid cells derived from extravascular hemolytic anemia, hereditary spherocytosis patients [15]. The results indicating there are existed a dysexpressed miR-451 expression pattern in early erythroid progenitors of $\beta$-thalassemia, and analysis the differential expression of miRNAs is a significative method to confirm the abnormity of erythroid differentiation. This method may be used as a novel tactics of gene therapy for hemoglobinopathies, for example sickle cell anemia and $\beta$-thalassemias.

miR-144 / 451 is necessary for erythroid homeostasis which were highly expressed during erythrocyte development. Mice with miR-144 / 451 ablation deletion exhibit a cell autonomous impairment of late erythroblast maturation, resulting in splenomegaly, erythroid hyperplasia and mild anemia [16]. Mice with miR-144 / 451 deletion also caused erythrocyte instability and increased sensibility to injure after exposure to oxidant drugs. The phenotype was profoundly conserved, as miR-451 knockdown cooperates with oxidant stress lead to significant anemia in zebrafish embryos [17]. miR-451 could directly suppress 14-3-3 $\zeta$ expression, which inhibited nuclear aggregation of FoxO3 (a positive modulator of erythroid anti-oxidant genes). Hence, the accumulation of 14-3-3 $\zeta$ caused partial relocalization of FoxO3 from cell nucleus to cytoplasm by inhibiting its transcriptional process in erythroblasts with miR-144 $/ 451^{-/}$. Meanwhile, $14-3-3 \zeta$ overexpression inhibited cell nuclear localization and activity of FoxO3 in erythroid cells and fibroblasts. Furthermore, 14-3-3 $\zeta$ knockdown protected miR-144 / 451 $1^{-/}$erythrocytes from peroxide-caused damage and restored catalase activity. The results demonstrated that miR-144 / 451 protects

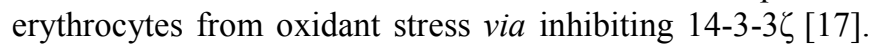

This study found a new miRNA-mediated network that protects erythrocytes from oxidant stress which might be regarded as new therapeutic methods directed at decreasing oxidative stress, a main issue in sickle cell anemia and thalassemia.

miR-144 / miR-451 expression level increased during EPO-induced TF1 cells erythroid differentiation, and miR-144 / miR-451 knockdown reduced TF1 cells erythroid differentiation [18]. miR-451 expression level also increased during erythroid maturation of hemin-induced K562 [19] and DMSO (dimethyl sulfoxide)-induced MEL cells [20], while miR-451 expression was not significantly changed in hemin-induced HEL cells, further, miR-451 overexpression accelerated erythropoiesis of K562 and MEL cells [19-21]. Moreover, miR-451 overexpression significantly induced erythroid differentiation and maturation of CD133+ stem cells in the lack of stimulatory cytokines and growth factors [22]. These results demonstrated miR-45 functions as a promoter of erythroid differentiation involved in modulation of erythropoiesis.

As a target of both miR-144 and miR-451, RAB14 negatively modulated human erythropoiesis, RAB14 overexpression counteracted the inhibitory action of miR-144 and miR-451 knockdown on erythropoiesis of TF1 cells, meanwhile, its knockdown rescued the inhibitory action of miR-144 and miR-451 depletion on erythropoiesis of TF1 cells. The results indicated that miR-144 / miR-451 via directly binding to RAB14 to regulate erythroid differentiation [18]. Furthermore, the leukemogenic RUNX1 / ETO (Runt Related Transcription Factor 1 / Myeloid translocation gene on chromosome 16) fusion protein emerged as a critical modulator of miRNA network, promoting differentiation at erythroid / megakaryocytic junction point, which could transcriptionally repress miR144 / 451 expression [23]. Moreover, miR-451 played an important role in facilitating erythroid maturation of zebrafish partially by directly targeting GATA2 (globin transcription factor 2) [24].

\section{2. $m i R-486, m i R-126-3 p$}

Hydroquinone (HQ) could inhibit erythropoiesis in a dose-dependent fashion. The expression levels of miR-486 and miR-126-3p were markedly decreased in CD34+ cells after treatment with HQ compared to untreated CD34+ cells by miRNA microarray analysis. miR-486 overexpression promoted erythroid differentiation of K562 cells and weaked the inhibitory effects on HQ-treated K562 cells erythroid differentiation. In addition, miR-486-5p expression level was negatively associated with the concentration of benzene inhalation on erythroid cell toxicity of C57BL / 6J mice. Especially, miR-486 downregulation occurred in male patients of chronic benzene poisoning [21]. The inhibition of miR-486 might be related with benzene-caused perturbation of erythropoiesis.

Further research found that miR-486 was markedly overexpressed in chronic myeloid leukemia (CML) than in CD34+ cells, especially in erythroid-megakaryocyte 
progenitor population and its expression was the highest in peripheral blood cells, meanwhile, miR-486 was increased during EPO- or GM-induced CD34+ cells erythroid differentiation [25, 26]. The overexpression / inhibition of miR-486 promoted / inhibited erythropoiesis and proliferation of CD34+ cells [25]. Meanwhile, the expression level of miR-486 rapidly increased in hypoxia-induced TF-1 cells, its overexpression / inhibition promoted / suppressed TF-1 cells erythroid differentiation and proliferation. Furthermore, Sirt1 was a target gene of miR-486 which could modulate hypoxia-induced erythroid differentiation. Mechanically, miR-486 could regulate the TF-1 cells erythropoiesis and proliferation abilities by directly targeting Sirt1 [27]. The results unveiled a novel biological regulation mechanism for miRNA-regulated gene transcription in connecting hypoxia to erythropoiesis of hematopoietic cells.

\section{3. $m i R-362, m i R-210$ and $m i R-188$}

miR-362, miR-210 and miR-188 play crucial role in erythropoiesis. miR-362, miR-210 and miR-188 were lowly expressed in GM-CSF-dependent UT-7 / GM cells compared to EPO-dependent UT-7 / EPO cells, moreover, the expression levels of miR-362, miR-210 and miR-188 were increased in EPO-treated UT-7 cells compared with GM-CSF-treated UT-7 cells [28].

miR-210 expression was 2-fold lower in TER-119-negative cells (TER-119 is an erythroid-specific antigen) than in TER-119-positive cells, and miR-210 expression level was significantly increased during erythroid saturation [28, 29]. miR-210 exhibiting different expression levels in erythroid precursor cells from one normal and two thalassemic patients expressing different levels of fetal hemoglobin, and miR-210 was highly expressed in erythroid precursor cells derived from hereditary persistence of fetal hemoglobin (HPFH) patients. Moreover, the expression level of miR-210 was increased in a dose- and time-dependent manner during erythroid differentiation of mithramycin (MTH)-induced K562 cells and EPO-induced erythroid precursor cells, and suppression of miR-210 significantly inhibited MTH-induced K562 cells erythroid differentiation [30]. PLC $\beta 1$ is a critical molecule in nuclear inositide signaling, which associates with cell cycle progression, differentiation and proliferation, PLC $\beta 1$ could regulate erythroid differentiation via miR-210. PLC $\beta 1$ overexpression resulted in decrease of miR-210 expression in K562 cells after treatment with MTH, vice versa, PLC $\beta 1$ knockdown increased the expression level of miR-210, suggesting PLC $\beta 1$ inhibited MTH-induced K562 cell erythropoiesis by inhibiting miR-210 expression [31]. Furthermore, miR-210 was also overexpressed in hypoxia-induced K562 and CD34+ cells erythroid differentiation, meanwhile, miR-210 silencing inhibited globin gene expression and retarded maturation of CD34+ and K562 cells [32], suggesting miR-210 promoted hypoxia-induced erythropoiesis and the process was partially regulated by miR-210.

\section{4. $m i R-107$, miR-181a}

miR-107 exhibited low expression in KCL-22 and K562 cells, the overexpression of miR-107 promoted sodium butyrate-induced erythroid differentiation of KCL-22 and K562 cells, while no effect on KCL-22 and K562 cells proliferation. Meanwhile, miR-107 promoted erythroid differentiation of KCL-22 and K562 cells by directly targeting Cacna2d1 [33], offering potential therapeutic methods for CML patients. miR-181a expression was also markedly downregulated in CML patients and K562 cells. Furthermore, miR-181a could promote the hemin-treated erythroid differentiation of K562 cells [34]. However, the potential mechanism of miR-181a on erythropoiesis is uncover.

\section{5. $m i R-199 b-5 p$}

As an erythroid differentiation associated miRNA, miR-199b-5p might play crucial role in erythroid differentiation. The expression of miR-199b-5p was increased during hemin-treated erythroid differentiation of K562 cells, and miR-199b-5p overexpression forced hemin-induced erythroid differentiation of K562 cells. Moreover, the upregulation of miR-199b-5p happened in a NF-E2- and GATA-1-dependent manner during erythrocyte maturation of K562 cells, meanwhile, NF-E2 and GATA-1 could activate the transcription of miR-199b-5p by binding to the upstream of miR-199b-5p gene locus. Furthermore, c-Kit as a target of miR-199b-5p, miR-199b-5p regulated erythropoiesis by inhibiting c-Kit expression [35]. The results established a functional connection among NF-E2 / GATA-1, miR-199b-5p and c-Kit, and provided novel insights into the linking of post-transcription and transcription modulation during erythropoiesis.

\section{6. $\operatorname{miR}-125 a$}

miR-125a was overexpressed in bone marrow (BM) CD34+ cells of myelodysplastic syndromes (MDS) patients compared to BM CD34+ cells from healthy donors, the expression level of miR-125a negatively correlated with MDS patient survival, meanwhile, miR-125a overexpression inhibited erythropoiesis of Ara-C-induced K562 and MyD88-induced MDS-L cells [36]. miR-125a might use as a potential therapeutic target and prognostic biomarker in MDS.

\section{7. $\operatorname{miR}-146 b$}

miR-146b expression gradually increased during erythroid differentiation of EPO-induced CD34+ and hemin-induced K562 cells, meanwhile, miR-146b overexpression / knockdown promoted / inhibited CD34+ and K562 cells erythroid differentiation. PDGFRA (platelet-derived growth factor $\alpha$ ) is a direct target of miR-146b, miR-146b overexpression / knockdown decreased / increased PDGFRA protein expression level during erythropoiesis, additionally, PDGFRA acted as a negative modulator of erythropoiesis, its expression level decreased during erythroid differentiation, moreover, rescue experiment demonstrated miR-146b mediated erythroid 
differentiation via regulation PDGFRA. Mechanically, miR-146b negatively regulated the PDGFRA / JNK / JUN / HEY1 pathway, and positively regulated GATA-1 expression which could be negatively regulated by HEY1 in hemin-treated K562 cells, furthermore, miR-146 was positively regulated by GATA-1. Overall, miR-146b, transcriptionally activated by GATA-1, promoted erythroid differentiation by regulating the PDGFRA / JNK / JUN / HEY1 pathway [37]. This study provided new insights into a regulatory loop of GATA-1, miR-146b and PDGFRA during erythropoiesis.

\section{8. $\mathrm{miR}-22$}

miR-22 could control the balance of megakaryocyte and erythroid differentiation from their common precursor. Megakaryopoiesis was promoted in miR-22 knockout mices after infection with lymphochoriomeningitis (LCMV) virus, whereas erythropoiesis was destroyed [38]. The result provided in vivo evidence that miR-22 played a crucial role in modulating erythropoiesis during infectious stress.

\section{9. $m i R-23 a / m i R-27 a / m i R-24$}

miR-23a, an important modulator of erythroid differentiation, overexpressed during EPO-induced CD34+ and hemin-induced K562 cells erythroid differentiation. Meanwhile, miR-23a expression upregulated during CD34+ cells erythroid differentiation in a GATA-1-dependent manner, and miR-23a could promote erythroid differentiation of CD34+ and K562 cells. Moreover, miR-23a knockdown blocked erythropoiesis in zebrafish and its overexpression enhanced mature erythroid populations in mice. Furthermore, as a downstream target of miR-23a, SHP2 could mediate erythroid differentiation [39]. Taken together, the results identified a novel GATA-1-miR-23a-SHP2 axis in erythropoiesis, increased GATA-1 expression promoted the accumulation of miR-23a in differentiated erythroid cells, and miR-23a promoted terminal erythropoiesis by directly repressing SHP2 expression [39].

Additional, miR-23a / miR-27a also positively regulated the expression of $\beta$-like globin gene by directly binding to KLF3 (krupple like factor 3) and SP1 (stimulatory protein 1) in K562 and CD34+ cells. Interestingly, miR-23a / miR-27a enhanced the transcription of $\beta$-like globin gene by inhibiting KLF3 and SP1 binding to the gene locus of $\beta$-like globin during erythropoiesis. Furthermore, KLF3 could suppress the expression of miR-23a27a24-2 cluster (named as miR-23a cluster) by binding to the CACCC sites in the promoter of miR-23a cluster, miR-23a cluster and KLF3 formed a positive feedback loop to promote $\beta$-like globin expression during erythropoiesis [40]. Meanwhile, miR-27a promotes hemin-induced erythroid differentiation of K562 cells by targeting CDC25B [41].

Furthermore, miR-27a or miR-24 overexpression accelerated erythropoiesis of $\mathrm{CD} 34+$ cells and mice, vice versa, miR-27 or miR-24 knockdown impaired erythropoiesis of CD34+ cells and zebrafish. In immature erythroid progenitor cells, GATA-2 to inhibit its transcription by occupying the miR-27a/24 promoter. When erythropoiesis proceeded, GATA-1 directly activated miR-27a/24 transcription, thus led to GATA-1-regulated displacement of GATA-2 from chromatin. Moreover, the mature miR-27a and miR-24 cooperatively inhibited GATA-2 translation and favoured the occupancy switch from GATA-2 to GATA-1, thus finishing a positive feedback loop to accelerate erythroid maturation [42]. The results provided a regulatory circuit mechanism that comprised GATA1/2 switch and miR-27a/24 in erythropoiesis.

\subsection{0. $\mathrm{miR}-16-2, \mathrm{miR}-34 a$}

miR-16-2 associated with erythropoiesis which involved in the abnormal expansion of erythroid cells with polycythemia vera. miR-16 expression level was significantly upregulated in CD34+ cells derived from polycythemia patients. miRNA-16-2 overexpression promoted erythroid cell maturation and proliferation of normal CD34+ cells, conversely, miRNA-16-2 knockdown reduced erythroid colonies of polycythemia vera CD34+ cells. Furthermore, miR-16-2 knockdown inhibited erythropoiesis of mice in vivo [43]. The deregulation of miR-16-2 contributed to erythropoiesis, however, the mechanism of miR-16-2 on erythropoiesis remains to be illuminated.

miR-34a overexpression increased $\mathrm{HbF}$ and $\gamma$-globin expression, and promoted K562 cells erythroid differentiation, meanwhile, miR-34a overexpression directly inhibited STAT3 expression, moreover, STAT3 could bind to the 5'-UTR of $\gamma$-globin [44]. The results indicated that miR-34a promoted K562 cells erythroid differentiation through indirectly regulated $\gamma$-globin expression by binding to STAT3.

\section{3. miRNA Inhibited Erythroid Differentiation}

Correspondingly, some miRNAs were negatively correlated with erythroid differentiation and supposed as erythroid differentiation suppressor. The upregulation of miR-218, miR-24, miR-320a, miR-221 / 222, miR-433, miR-200a, miR-223, miR-150, miR-34a-5p, miR-124, miR-Let-7d, miR-376a, miR-155, miR-126 / 126*, miR-103, miR-15a, miR-30a-5p, miR-26a-5p, miR-669m, miR-9 inhibited erythroid differentiation, as summarized in Table 2 . These miRNAs have the potential in the future as biomarkers for the diagnosis, therapy and prognosis of blood disease.

\section{1. $\mathrm{miR}-218$}

miR-218 targeted and inhibited ALAS2 (delta-aminolevulinate synthase 2) expression through directly targeting to its $3^{\prime}$-UTR. miR-218 overexpression significantly changed iron metabolism and suppressed hemin-induced erythroid differentiation of K562 cells, which consistent with the effect of ALAS2 silencing in K562 cells [45]. Taken together, miR-218 changed iron metabolism and suppressed inhibited erythropoiesis via directly targeting ALAS2. 
Table 2. miRNAs inhibited erythroid differentiation.

\begin{tabular}{|c|c|c|c|c|}
\hline miRNA & $\begin{array}{l}\text { Experimental } \\
\text { model system }\end{array}$ & Biological effect & Target and mechanism & Ref \\
\hline miR-218 & K562 & $\begin{array}{l}\text { miR- } 218 \text { repressed hemin-induced erythroid differentiation and } \\
\text { altered iron metabolism of K562 cell }\end{array}$ & $\begin{array}{l}\text { miR-218 inhibited erythroid } \\
\text { differentiation and altered iron } \\
\text { metabolism by targeting ALAS2 }\end{array}$ & {$[45]$} \\
\hline miR-320a & K562 & $\begin{array}{l}\text { miR-320a inhibited hemin-induced erythroid differentiation of } \\
\text { K562 cell }\end{array}$ & $\begin{array}{l}\text { miR-320a inhibited erythroid } \\
\text { differentiation by targeting SMAR1 via } \\
\text { binding to the promoter of miR-221 / } 222\end{array}$ & [46] \\
\hline miR-221 / 222 & K562, mice & $\begin{array}{l}\text { miR-221 / } 222 \text { decreased during Emodin- and hemin-induced } \\
\text { erythroid differentiation of K562 cell; miR-221 / } 222 \text { inhibited } \\
\text { erythropoiesis and growth of K562, CD34+ and TF-1 cells; } \\
\text { miR } 221 \text { / } 222 \text { impaired CD } 34+\text { engraftment upon } \\
\text { transplantation } \\
\text { into NOD-SCID mice }\end{array}$ & $\begin{array}{l}\text { miR-221 / } 222 \text { inhibited erythropoiesis } \\
\text { and erythroleukemic cell growth by } \\
\text { targeting Kit, BLVAR and CRKL }\end{array}$ & [47-49] \\
\hline $\operatorname{miR}-433$ & $\mathrm{CD} 34+, \mathrm{TF}-1$ & $\begin{array}{l}\text { miR-433 negatively regulated EPO-induced proliferation and } \\
\text { erythroid differentiation of CD34+ and TF-1 cells }\end{array}$ & $\begin{array}{l}\text { miR-433 inhibited hematopoietic cell } \\
\text { proliferation and erythropoiesis by } \\
\text { targeting GBP2 }\end{array}$ & {$[50]$} \\
\hline miR-200a & $\begin{array}{l}\text { HSC, K562, } \\
\text { TF-1, zebrafish }\end{array}$ & $\begin{array}{l}\text { miR-200a downregulated in HSC, hemin-induced K562 and } \\
\text { EPO-induced TF-1 cells erythroid differentiation; miR-200a } \\
\text { overexpression inhibited erythroid differentiation and primitive } \\
\text { erythropoiesis of K562, TF-1 cells and zebrafish }\end{array}$ & $\begin{array}{l}\text { miR-200a inhibited erythroid } \\
\text { differentiation by targeting PDCD4 and } \\
\text { THRB }\end{array}$ & [51] \\
\hline miR-223 & CD34+, K562 & $\begin{array}{l}\text { miR-223 down-regulated during hemin-induced erythroid } \\
\text { differentiation of K562 cell; miR-223 overexpression inhibited } \\
\text { EPO-induced CD } 34+\text { and hemin-induced K562 erythroid cells } \\
\text { differentiation and erythroid colony formation }\end{array}$ & $\begin{array}{l}\text { miR-223 reversibly regulated erythroid } \\
\text { differentiation by targeting LMO2 }\end{array}$ & $\begin{array}{l}{[52,} \\
53]\end{array}$ \\
\hline $\operatorname{miR}-150$ & $\begin{array}{l}\text { CD } 34+, \text { K562, } \\
\text { CD133+ }\end{array}$ & $\begin{array}{l}\text { miR-150 decreased during EPO-induced CD34+ and } \\
\text { hemin-induced K562 cells erythroid differentiation; miR-150 } \\
\text { overexpression inhibited CD133+, EPO-induced CD34+ and } \\
\text { hemin-induced K562 cells erythroid differentiation }\end{array}$ & $\begin{array}{l}\text { miR-150 inhibited erythroid proliferation } \\
\text { via inducing apoptosis and blocking cell } \\
\text { cycle }\end{array}$ & {$[9,54]$} \\
\hline $\operatorname{miR}-34 a-5 p$ & CD34+, K562 & $\begin{array}{l}\text { miR-34a-5p down-regulated during hemin-induced K562 and } \\
\text { EPO-induced CD } 34+\text { cells erythroid differentiation; } \\
\text { miR-34a-5p overexpression / knockdown inhibited / promoted } \\
\text { K562 cell erythroid differentiation }\end{array}$ & $\begin{array}{l}\text { miR-34a-5p inhibited erythroid } \\
\text { differentiation of by targeting c-MYB }\end{array}$ & [55] \\
\hline miR-124 & $\begin{array}{l}\mathrm{CD} 34+, \mathrm{K} 562 \\
\text { mice }\end{array}$ & $\begin{array}{l}\text { miR-124 down-regulated during hemin-induced K562 and } \\
\text { EPO-induced CD } 34+\text { cells erythroid differentiation; miR-124 } \\
\text { negatively regulated erythropoiesis in xenograft mice }\end{array}$ & $\begin{array}{l}\text { miR-124 inhibited erythroid } \\
\text { differentiation through targeting c-MYB } \\
\text { and TAL1 }\end{array}$ & [56] \\
\hline miR-Let-7d & $\begin{array}{l}\text { K562, HEL, } \\
\text { CD34+ }\end{array}$ & $\begin{array}{l}\text { miR-Let-7d decreased during induced erythroid differentiation } \\
\text { of K562, HEL and CD34+ cells }\end{array}$ & $\begin{array}{l}\text { miR-Let-7d inhibited erythroid } \\
\text { differentiation by accumulation of iron in } \\
\text { endosomes via targeting DMT1 }\end{array}$ & [57] \\
\hline miR-376a & CD34+, K562 & $\begin{array}{l}\text { miR-376a down-regulated during hemin-induced K562 and } \\
\text { EPO-induced CD34+ cells erythroid differentiation; miR-376a } \\
\text { overexpression / knockdown inhibited / promoted K562 and } \\
\text { CD34+ cells erythroid differentiation }\end{array}$ & $\begin{array}{l}\text { miR-376a repressed erythroid } \\
\text { differentiation by targeting Ago2 and } \\
\text { CDK2 }\end{array}$ & {$[58]$} \\
\hline miR-155 & $\begin{array}{l}\text { normal human } \\
\text { erythroid } \\
\text { progenitors }\end{array}$ & $\begin{array}{l}\text { miR-155 decreased during erythroid differentiation of purified } \\
\text { normal human erythroid progenitors }\end{array}$ & & {$[14]$} \\
\hline miR-103 & CD34+, K562 & $\begin{array}{l}\text { miR-103 down-regulated during hemin-induced K562 and } \\
\text { EPO-induced CD } 34+\text { cells erythroid differentiation }\end{array}$ & & [59] \\
\hline $\begin{array}{l}\text { miRs-126 } \\
126^{*}\end{array}$ & CD34+ & $\begin{array}{l}\text { miRs-126 / 126* down-regulated in CD } 34+\text { cell during EB } \\
\text { differentiation; Induction of miRs-126 / } 126 * \text { during both EB } \\
\text { differentiation and colony formation reduced the number of } \\
\text { erythroid colonies }\end{array}$ & $\begin{array}{l}\text { miRs- } 126 \text { / } 126^{*} \text { negatively regulated } \\
\text { erythropoiesis by targeting PTPN9 }\end{array}$ & {$[60]$} \\
\hline miR-15a & CD34+ & $\begin{array}{l}\text { miR-15a downregulated during EPO-induced erythroid } \\
\text { differentiation of CD34+ cell; miR-15a overexpression blocked } \\
\text { both erythroid and myeloid colony formation of CD34+ cell }\end{array}$ & $\begin{array}{l}\text { A c-MYB-miR-15a autoregulatory } \\
\text { feedback loop contributed to } \\
\text { hematopoiesis }\end{array}$ & [61] \\
\hline $\begin{array}{l}\text { miR-30a-5p, } \\
\text { miR-26a-5p } \\
\text { miR-669m }\end{array}$ & K562, mice & $\begin{array}{l}\text { miR-26a-5p and miR-30a-5p knockdown promoted erythroid } \\
\text { differentiation of K } 562 \text { cells; miR- } 669 \mathrm{~m} \text { was not expressed in } \\
\text { the erythroblast; overexpression of miR- } 669 \mathrm{~m} \text { inhibited } \\
\text { erythroid differentiation in mice. }\end{array}$ & $\begin{array}{l}\text { Akap } 7 \text { and } \mathrm{Xk} \text { are possibly responsible } \\
\text { for the miR-669m-induced } \\
\text { erythropoiesis impairment }\end{array}$ & {$[62]$} \\
\hline miR-9 & $\begin{array}{l}\text { G1ER, fetal } \\
\text { liver-derived } \\
\text { erythroblasts, } \\
\text { mice }\end{array}$ & $\begin{array}{l}\text { miR-9 was highly expressed in mature myeloid cells but at } \\
\text { relatively low levels in erythroid cells; miR-9 overexpression } \\
\text { inhibited differentiation with an increase in reactive oxygen } \\
\text { species (ROS) production in vitro and in vivo. }\end{array}$ & $\begin{array}{l}\text { miR-9 blocks erythropoiesis by } \\
\text { deregulating FoxO3-mediated pathways }\end{array}$ & [64] \\
\hline
\end{tabular}




\section{2. $m i R-320 a, m i R-221 / 222$}

miR-320a negatively regulated the expression of SMAR1 via targeting to its $3^{\prime}-\mathrm{UTR}$, moreover, miR-320a inhibited hemin-induced K562 cells erythroid differentiation by targeting SMAR1, moreover, SMAR1 expression negatively correlated with miR-320a expression during erythroid differentiation. Furthermore, SMAR1 could regulate erythropoiesis via binding to the promoter of miR-221 / 222 which were the first found miRNAs associated with erythroid differentiation [46]. Transplantation experiments revealed that miR-221 / 222 treatment of CD34+ cells impaired engraftment capacity and stem cell activity of NOD-SCID mice [47]. Furthermore, miR-221 / 222 expression decreased during Emodin- and hemin-induced K562 cells erythroid differentiation [48]. Meanwhile, miR-221 / 222 could inhibit erythropoiesis and growth of K562, CD34+ and TF-1 cells by targeting Kit, BLVAR and CRKL [47, 49]. Overall, the above results demonstrated that miR-320a inhibited erythropoiesis by directly targeting SMAR1 via binding to the promoter of $\operatorname{miR}-221 / 222$.

\section{3. $m i R-433, m i R-200 a$}

Compared with normal subjects, miR-433 was upregulated in CD34+ cells from negative myeloproliferative neoplasms (MPN) patients, it also upregulated during normal erythropoiesis, however, miR-433 negatively regulated EPO-induced erythropoiesis and proliferation abilities of CD34+ cells. GBP2 (guanylate binding protein 2), a direct target of miR-433, was decreased during erythropoiesis and positively regulated EPO-induced erythropoiesis and proliferation of TF-1 cells, demonstrating miR-433 inversely regulated erythropoiesis and proliferation of hematopoietic cell via targeting GBP2 [50].

miR-200a exhibited downregulated expression pattern during erythroid differentiation of human HSC, EPO-induced TF-1 and hemin-induced K562 cells. Moreover, miR-200a overexpression inhibited erythroid differentiation of TF-1 and K562 cells. Further in vivo experiment demonstrated miR-200a overexpression inhibited primitive erythropoiesis of zebrafish. Additionally, PDCD4 and THRB were targets of miR-200a, the two molecules could promote erythroid gene expression [51]. In general, miR-200a inhibited erythropoiesis via directly binding to PDCD4 and THRB.

\section{4. $m i R-223$}

miR-223 was down-regulated in CD34+ cells, whereas LMO2 (LIM domain only 2), a crucial molecule for erythropoiesis, was overexpressed. miR-223 overexpression reduced the expression level of $\mathrm{LMO} 2$ by binding to 3'-UTR-LMO2, and impaired the EPO-induced erythroid differentiation and erythroid colony formation of CD34+ cells [52]. Accordingly, knockdown of LMO2 mimics the action of miR-223 overexpression [52]. Meanwhile, miR-223 expression was decreased during erythroid differentiation of hemin-induced K562 cells, miR-223 overexpression significantly decreased $\gamma$-globin expression and benzidine-positive K562 cells, further indicating an inhibitory role of miR-223 on erythropoiesis [53]. Mechanically, miR-223 negatively regulated erythropoiesis of K562 cells through downregulating LMO2 expression, and miR-223 downregulation was necessary for erythroid progenitor recruitment and commitment that results in extension of erythroblast cells at least partially regulated by promoting LMO2 expression.

\section{5. miR-150, miR-34a-5p}

miR-150 expression decreased during EPO-induced CD34+ and hemin-induced K562 cells erythroid differentiation, miR-150 overexpression also inhibited EPO-induced CD34+ and hemin-induced K562 cells erythroid differentiation, meanwhile, miR-150 overexpression suppressed hemin-induced erythroid proliferation ability of K562 via blocking cell cycle and inducing apoptosis [54]. Furthermore, miR-150 could be as an efficient alternative to stimulatory cytokines for CD133+ cells differentiation into erythroid lineage, miR-150 knockdown positively regulated genes expression of CD235a, GATA-1, EKLF, FOG-1, CD71 and induced hemoglobinization efficiently of CD133+ cells in the lack of extrinsic factors [9]. The above results indicated that regulation of stem cell erythropoiesis through miRNA provides promising potential for vascular tissue engineering and regenerative medicine applications.

miR-34a-5p expression level was decreased during erythroid differentiation of EPO-induced CD34+ and hemin-induced K562 cells. miR-34a-5p overexpression attenuated K562 cells erythroid differentiation, in contrast, miR-34a-5p inhibition accelerated erythroid phenotypes of K562 cells. miR-34a-5p could inhibit erythroid differentiation of K562 cells by directly targeting c-MYB [55].

\section{6. miR-124, miR-Let-7d}

miR-124 was decreased during cells erythroid differentiation of EPO-induced CD34+ and hemin-induced $\mathrm{K} 562$, and miR-124 inhibited erythropoiesis via directly targeting c-MYB and TAL1. Meanwhile, miR-124 also inversely regulated erythroid differentiation in xenograft mice. miRNA biosynthesis is precisely controlled by post-transcriptional mediators, containing RBPs, QKI5 (quaking 5), an RBP, could activate the primary miR-124-1 biosynthesis processing during erythroid differentiation. QKI5 recognized a distal QKI response element and interacted with DGCR8 to recruit microprocessor, then the recruited microprocessor was taken to primary miR-124-1 stem loops by a spatial RNA-RNA interaction. As erythropoiesis proceeds, the accompanying reduce of QKI5 released microprocessor from primary miR-124-1 and reduced mature miR-124 expression to accelerate maturation of erythrocytes [56]. The results demonstrated the crucial effect of QKI5 in miRNA biosynthesis processing during erythroid differentiation.

DMT1 is a metal-iron transporter protein which broadly expressed in erythroid cells. miR-Let-7d expression decreased 
while DMT1 expression increased during induced erythropoiesis of HEL, K562 and CD34+ cells, meanwhile, miR-Let-7d overexpression decreased DMT1-IRE expression by binding to its 3'-UTR. Furthermore, miR-Let-7d overexpression caused iron accumulation in the endosomes which influences the iron available by erythroid cells for heme synthesis [57], indicating miR-Let-7d inhibited erythropoiesis through accumulation of iron in endosomes via targeting DMT1-IRE.

\section{7. $m i R-376 a, m i R-155, m i R-103$}

miR-376a expression was markedly decreased during erythroid differentiation of K562 and CD34+ cells, meanwhile, its overexpression suppressed the EPO-induced CD34+ and hemin-induced K562 cells erythroid differentiation, while miR-376a downregulation promoted the hemin-induced erythroid differentiation of K562 cells. Mechanistically, miR-376a repressed erythropoiesis of K562 cells by targeting Ago2 (argonaute 2) and CDK2 (cyclin-dependent kinases 2) [58]. Moreover, miR-155 expression level decreased 200-fold during erythroid differentiation of purified normal human erythroid progenitors [14], suggesting miR-155 might as a crucial molecule in erythropoiesis of normal erythroid progenitors. miR-103 also exhibited down-regulation following erythroid induction in K562 and CD34+ cells [59], indicating miR-103 exhibits inhibitory role in erythroid differentiation.

\section{8. $m i R s-126 / 126 *$, miR-15a}

The expression of miRs-126 / 126* was consistently decreased during embryoid body (EB) differentiation of CD34+ cells, and its overexpression decreased the number of erythroid colonies during EB differentiation, indicating suppressive effect of miRs-126/126* on erythroid differentiation. PTPN9, a target of miR-126 / 126*, could partially relieved the inhibited erythroid differentiation induced by miRs-126 / $126^{*}$ [60]. The study indicated that miRs-126 / 126* negatively regulated erythropoiesis by targeting PTPN9.

miR-15a overexpression could inhibit erythroid and myeloid colony formation abilities of CD34+ cells. miR-15a directly binds to the $c-M Y B-3^{\prime}-\mathrm{UTR}$ to decrease its expression, meanwhile, c-MYB directly regulated miR-15a expression via targeting to the promoter of miR-15a, moreover, the expression levels of miR-15a and c-MYB were negatively related during erythroid differentiation of CD34+ cells [61]. In general, a novel miR-15a-c-MYB regulatory circuitry was discovered in erythroid differentiation.

\section{9. $m i R-30 a-5 p, m i R-26 a-5 p, m i R-669 m$}

Knockdown of miR-26a-5p and miR-30a-5p are ought to induce terminal erythroid differentiation of K562 cells. miR-26a-5p and miR-30a-5p knockdown resulted in significant down-regulation of CD45 and up-regulation of CD71 and the increase in hemoglobin production [62]. Meanwhile, miR-669m was not expressed in the erythroblast, miR-669m overexpression inhibited erythroid differentiation in mice, Akap7 and Xk, the two target genes of miR- $669 \mathrm{~m}$, are responsible for the miR-669m-induced erythropoiesis damage, implying manipulates these genes might be a therapeutic approach for erythropoiesis dysfunction [63].

\subsection{0. $\operatorname{miR}-9$}

miR-9 was overexpressed in acute leukemia, and it was highly expressed in mature myeloid cells but at relatively lower level in erythroid cells. Meanwhile, miR-9 overexpression inhibited erythroid differentiation of G1ER cells and fetal liver-derived erythroblasts in vitro. Furthermore, miR-9 overexpression blocked erythroid differentiation in vivo. Interestingly, miR-9 overexpression significantly blocks erythroid progenitor cells differentiation with an increase in reactive oxygen species (ROS) production. Mechanistically, miR-9 blocks erythropoiesis by deregulating FoxO3-mediated pathways, which may contribute to the ineffective erythropoiesis observed in patients with hematological malignancies [64].

\section{Paradoxical Roles of miR-24 in Erythroid Differentiation}

miR-24 is the second miRNA whose function involved in erythropoiesis was illuminated, however, the potential exact role of miR-24 is controversial, as summarized in Table 3. miR-24 directly interfered with activin signaling by directly targeting ALK4-3'-UTR (anaplastic lymphoma kinase 4, activin type I receptor) and decreasing the expression of ALK4, thus weaken activin-induced erythroid differentiation of CD34+ and K562 cells. Meanwhile, miR-24 expression was negatively associated with ALK4 during erythroid differentiation, this finding demonstrated a modulation style of miR-24 on erythroid differentiation via inhibiting ALK4 expression. The data indicated miR-24 negatively modulates erythroid differentiation through regulating the activin signaling pathway [65].

However, far from the inhibition role of miR-24 in erythroid differentiation, one research presented exactly opposite data and perspectives, the expression of miR-24 increased during erythropoiesis of EPO-induced CD34+ and hemin-induced K562 cells, furthermore, miR-24 promoted erythroid differentiation by directly targeting $\mathrm{Sp} 1$ via increasing the expression of $\gamma$-globin and $\varepsilon$-globin [66]. We think the conflict results might come from the different inducer. The exact functional role of miR-24 involved in erythropoiesis need further confirmation and the in vivo function still need to investigated to better comprehend the biological significance of miR-24. 
Table 3. Paradoxical roles of miR-24 in erythroid differentiation.

\begin{tabular}{lllll}
\hline miRNA & $\begin{array}{l}\text { Experimental model } \\
\text { system }\end{array}$ & Biological effect & Target and mechanism & Ref \\
\hline miR-24 & K562, CD34+ & $\begin{array}{l}\text { miR-24 inhibited activin-induced erythroid differentiation and } \\
\text { promoted proliferation of K562 and CD34+ cells } \\
\text { miR-24 expression increased during hemin-induced K562 and } \\
\text { EPO-induced CD34+ cells erythroid differentiation; miR-24 } \\
\text { miR-24 }\end{array}$ & K562, CD34+ & $\begin{array}{l}\text { miR-24 inhibited erythroid } \\
\text { differentiation by targeting ALK4 }\end{array} \quad \begin{array}{l}\text { miR-24 promoted erythroid } \\
\text { differentiation by targeting Sp1 }\end{array}$ \\
\hline
\end{tabular}

\section{Conclusions}

Hematopoiesis is a accurately regulated multi-step process including HSCs self-renew and hematopoietic stem / progenitor cells differentiation. How HSCs undergo linage commitment and evolve into a variety of mature blood cells has been a hotspot for many years [7-9]. There are now strong evidences that miRNAs are important regulators of hematopoiesis, which could regulate hematopoietic commitment, differentiation, apoptosis and proliferation of hematopoietic cells. miRNAs represent a family of non-coding small RNAs, which are capable of causing mRNA degradation, inhibiting protein translation and modulating various crucial cellular processes, containing cell differentiation, metastasis, proliferation, chemoresistance [1, 2]. About 3000 recognized miRNAs exist in species ranging from humans to plants, indicating a common evolutionary mechanism of mediation gene expression.

miRNAs, are crucial modifier of erythropoiesis, could

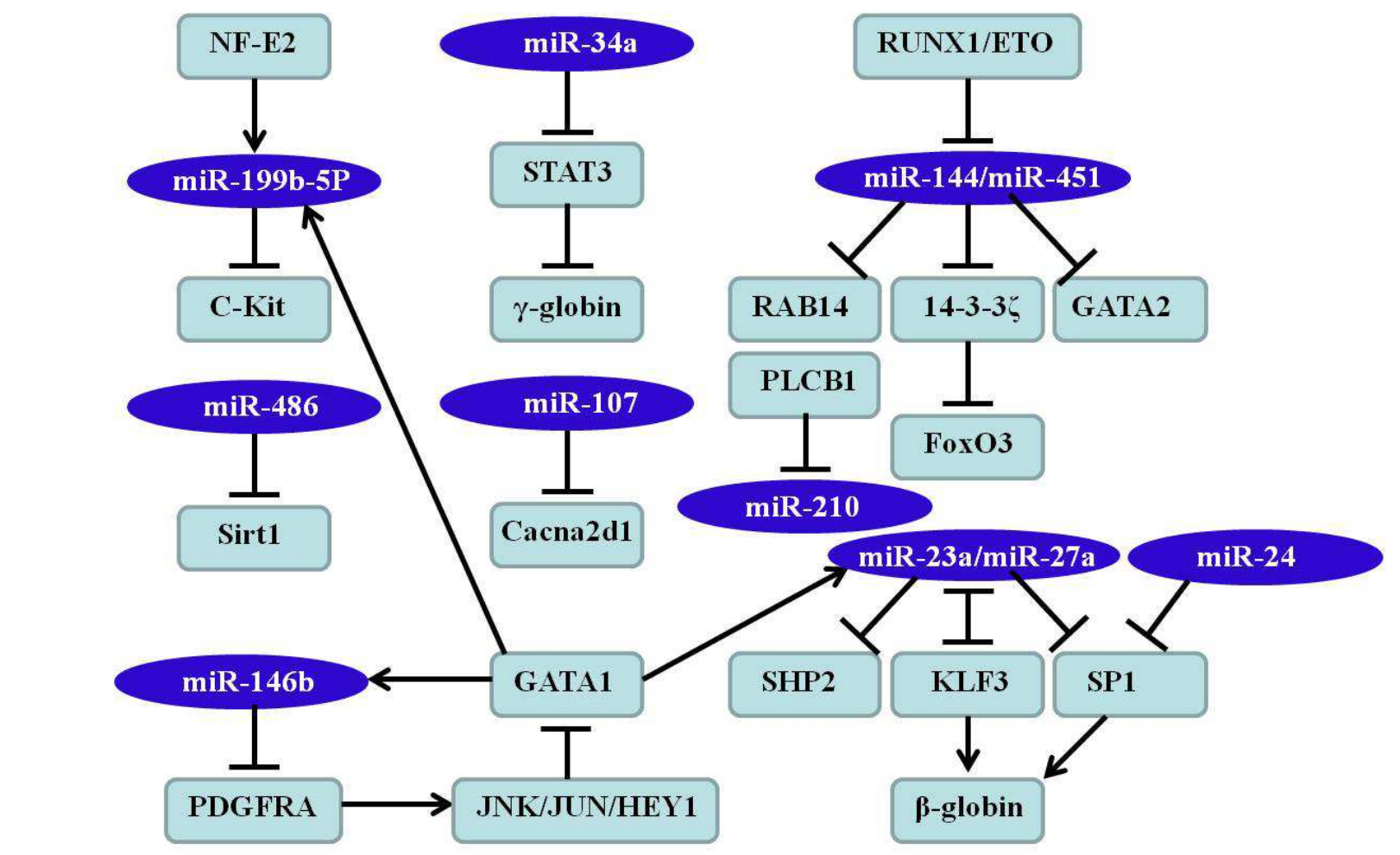

Figure 2. The targets and schematic regulation mechanism of miRNAs promoted erythroid differentiation. affect the transcription factors expression which necessary for erythropoiesis. Until now, miR-144 / miR-451, miR-486, miR-126-3p, miR-107, miR-199b-5p, miR-362, miR-188, miR-210, miR-125a, miR-146b, miR-22, miR-23a / miR-27a / miR-24, miR-16, miR-34a, miR-15a, miR-218, miR-320a, miR-221 / 222, miR-433, miR-200a, miR-223, miR-150, miR-30a-5p, miR-26a-5p, miR-669m, miR-9, miR-34a-5p, miR-124, miR-Let-7d, miR-376a, miR-155, miR-126 / 126*, miR-103 and miR-24 have been reported to be associated with erythropoiesis. A miRNA can target one or more mRNAs, usually in combination with other miRNAs, miRNAs operate in highly complex regulatory networks. miRNAs reversely modulate gene expression by inducing degradation and suppressing translation of targeted mRNAs. They can function via a few pathways which are involved in erythroid differentiation. According to our summary and analysis, the targets and integrated underlying mechanisms of miRNAs involved in erythroid differentiation were hypothesized and illustrated in Figure 2 and Figure 3. 


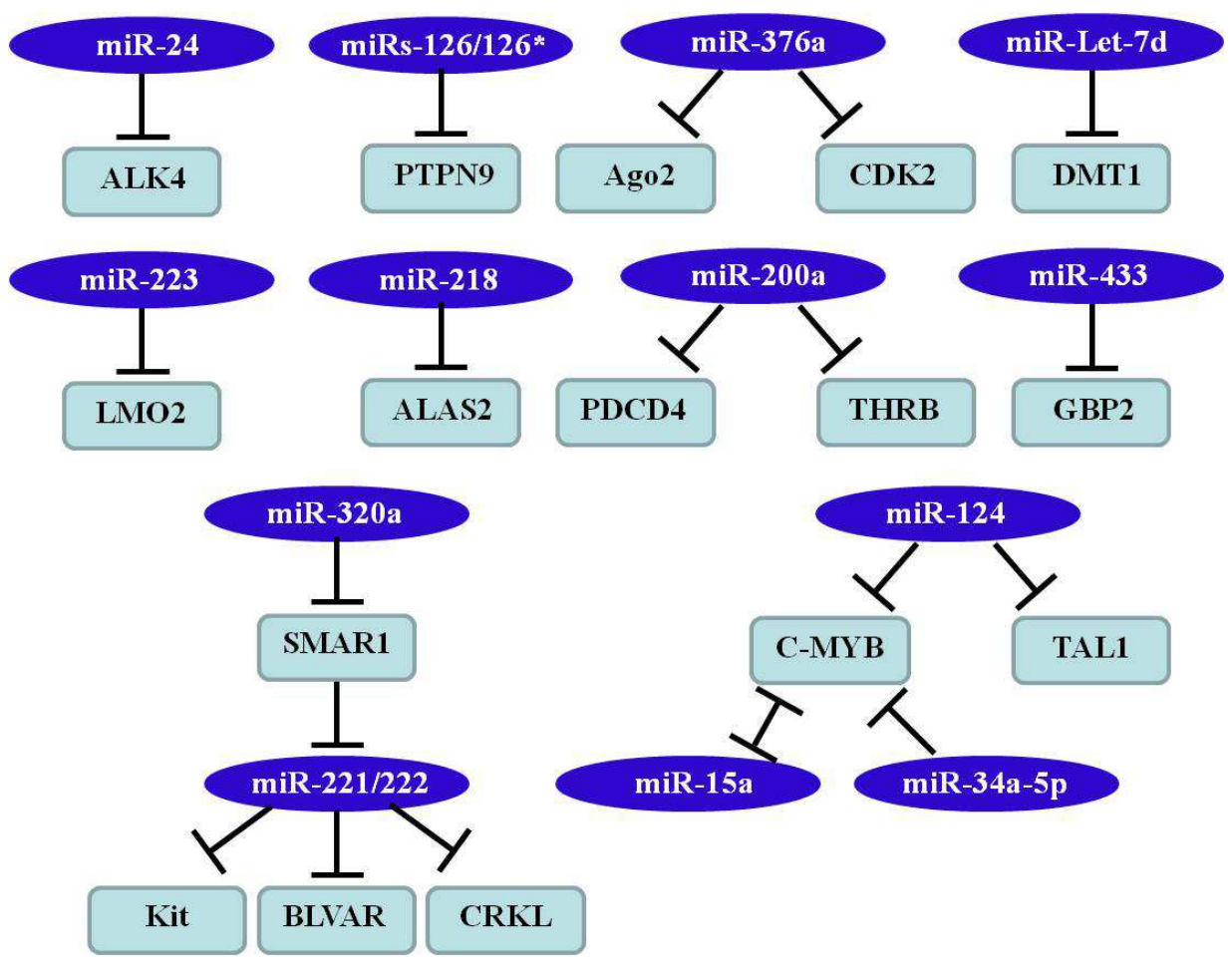

Figure 3. The targets and schematic regulation mechanism of miRNAs inhibited erythroid differentiation.

miRNAs considered as potential targets for cancer and blood diseases therapy. Gain- and loss- of function experiments will provide a better thought about the clinical application of miRNAs. The find of miRNAs which involved in blood disorders has two vital significances: the first is the development of novel diagnostic and prognostic tools, the second is the development of new therapies. miRNA-based therapies bring a goodly prospect, particularly in the area of oncology research, in vivo to inhibit miRNA function provide new exciting opportunities for treatment. There are two ways about miRNA-based therapies: miRNA replacement and miRNA silencing. In miRNA silencing therapy, single-stranded locked nucleic acid (anti-miRNA) bind to miRNA complementarily, preventing the miRNA from binding to target mRNAs $[3,6]$. In miRNA replacement therapy, miRNA is reintroduced using a miRNA mimic, these double-stranded miRNA mimics can either be packaged in nanoparticles to enhance their stability or modified on the complementary strand $[3,6]$. The transportation of miRNA mimics and anti-miRNA can be boosted with nanoparticles conjugated to antibodies or cancer-specific ligands $[3,6]$. Although miRNA antagonists and mimics are capable of imitating and silencing, these mimics or antagomirs have not yet been used to therapy certain blood diseases in clinical trials. The intriguing method is expected to bring crucial creative tactics in blood disorders. With respect to miRNA-based clinical experiments, only NCT01108159 was used in the field of hematological to discover changed mRNA / miRNA expression which involved in the development, progression and therapeutic response of hematological diseases. In spite of there are remain a variety of challenges to conquer before miRNA therapeutics can be used clinically, it is predicted that in the near future, miRNA-based therapeutics may offer significant progress in hematologic disorders. Further researches are needed to find more target molecules of miRNA and obtain a better comprehending of the underlying action mechanisms of miRNA involved in erythroid differentiation.

Taken together, the study on the function role of miRNAs in erythropoiesis has significant underlying value not only for comprehending blood diseases development and progression, but also for searching new diagnostic and therapeutic methods. Although we have learned more about the function of miRNAs in production of erythrocytes, the physiological and biological function role of these miRNAs still immensely mysterious, because of a variety of studies were investigated in passage cells instead of primary cells. Even though passage cells are readily obtainable and can be easily operated, there are a lot of examples where phenotypes observed in vitro contrast with those observed when molecules are mutated in vivo. In view of this, more researches should to be concentrated on the animal models for the coincident and dependable results which will enable us to thoroughly understand the pathobiology of erythropoiesis in the future. A better understanding of important regulator miRNAs of erythroid differentiation may provide novel choices for developing more effective therapeutic method for human blood diseases. We hope the current work will offer an up-to-date references for the most recent progresses in erythroid differentiation study of miRNA.

\section{Summary and Perspective}

An in-depth understanding the molecular mechanisms of erythropoiesis is exceedingly crucial for not only generating 
abundant amounts of erythroid cells in vitro or ex vivo for transplantation and therapeutics (which will possibly overcome present obstacles in the fields of bulk RBC production due to the lack of blood donor resources and high costs), but also for offering the chance to mediate the pathological dyserythropoiesis. During the last decade, efficient technology to produce RBC ex vivo using primary HSCs, embryonic stem cells or induced pluripotent stem cells, have become an increasing. Certain miRNAs are related with the erythropoiesis. The correlation of miRNAs related to erythropoiesis as well as its detailed underlying molecular mechanism, need to be explored. We expect some miRNAs to be used as underlying biomarkers and targets for diagnosis and therapy of some blood diseases, leading to promising prospects in blood diseases therapy.

\section{Acknowledgements}

This work was supported by the Natural Science Foundation of Liaoning (LQ2017001, 20181550168, LZ2020045) and the National Natural Science Foundation of China (31900517).

\section{References}

[1] Fang YX, Gao WQ. Roles of microRNAs during prostatic tumorigenesis and tumor progression. Oncogene. 2014; 33 (2): 135-147.

[2] Calin GA, Croce CM. MicroRNA signatures in human cancers. Nat Rev Cancer. 2006; 6 (11): 857-866.

[3] Bartel DP. MicroRNAs: target recognition and regulatory functions. Cell. 2009; 136 (2): 215-233.

[4] Zimmerman AL, Wu S. MicroRNAs, cancer and cancer stem cells. Cancer Lett. 2011; 300 (1): 10-9.

[5] Callegari E, Gramantieri L, Domenicali M, D'Abundo L, Sabbioni S, Negrini M. MicroRNAs in liver cancer: a model for investigating pathogenesis and novel therapeutic approaches. Cell Death Differ. 2015; 22 (1): 46-57.

[6] Undi RB, Kandi R, Gutti RK. MicroRNAs as haematopoiesis regulators. Adv Hematol. 2013: 695754.

[7] Zhao CH, Sun XL, Li LM. Biogenesis and function of extracellular miRNAs. ExRNA. 2019; 1 (1): 1-9.

[8] Fatica A, Rosa A, Fazi F, Ballarino M, Morlando M, De Angelis FG, et al. MicroRNAs and hematopoietic differentiation. Cold Spring Harb Symp Quant Biol. 2006; 71 (1): 205-210.

[9] Kouhkan F, Hafizi M, Mobarra N, Mossahebi-Mohammadi M, Mohammadi S, Behmanesh M, et al. MiRNAs: a new method for erythroid differentiation of hematopoietic stem cells without the presence of growth factors. Appl Biochem Biotechnol. 2014; 172 (4): 2055-2069.

[10] Eggold JT, Rankin EB. Erythropoiesis, EPO, macrophages, and bone. Bone. 2019; 119: 36-41.

[11] Vinchi F. Erythroid differentiation: a matter of proteome remodeling. Hemasphere. 2018; 2 (1): e26.

[12] Cullen BR. Transcription and processing of human microRNA precursors. Molecular Cell. 2004; 16 (6): 861-865.

[13] Deb B, Uddin A, Chakraborty S. miRNAs and ovarian cancer: An overview. J Cell Physiol. 2018; 233 (5): 3846-3854.

[14] Masaki S, Ohtsuka R, Abe Y, Muta K, Umemura T. Expression patterns of microRNAs 155 and 451 during normal human erythropoiesis. Biochem Biophys Res Commun. 2007; 364 (3): 509-514.

[15] Svasti S, Masaki S, Penglong T, Abe Y, Winichagoon P, Fucharoen S, et al. Expression of microRNA-451 in normal and thalassemic erythropoiesis. Ann Hematol. 2010; 89 (10): 953-958.

[16] Rasmussen KD, Simmini S, Abreu-Goodger C, Bartonicek N, Di Giacomo M, Bilbao-Cortes D, et al. The miR-144 / 451 locus is required for erythroid homeostasis. J Exp Med. 2010; 207 (7): 1351-1358.

[17] Yu DN, Santos CO, Zhao GW, Jiang J, Amigo JD, Khandros E, et al. MiR-451 protects against erythroid oxidant stress by repressing 14-3-3ל. Genes Dev. 2010; 24 (15): 1620-1633.

[18] Kim MJ, Tan YS, Cheng WC, Kingsbury TJ, Heimfeld S, Civin1 CI. MIR144 and MIR451 regulate human erythropoiesis via RAB14. Br J Haematol. 2015; 168 (4): 583-597.

[19] Bruchova-Votavova H, Yoon D, Prchal JT. MiR-451 enhances erythroid differentiation in K562 cells. Leuk Lymphoma. 2010; 51 (4): 686-693.

[20] Zhan M, Miller CP, Papayannopoulou T, Stamatoyannopoulos $\mathrm{G}$, Song $\mathrm{CH}$. MicroRNA expression dynamics during murine and human erythroid differentiation. Exp Hematol. 2007; 35 (7): 1015-1025.

[21] Liang BX, Chen YC, Yuan WX, Qin F, Zhang Q, Deng N, et al. Down-regulation of miRNA-451a and miRNA-486-5p involved in benzene-induced inhibition on erythroid cell differentiation in vitro and in vivo. Arch Toxicol. 2018; 92 (1): 259-272.

[22] Kouhkan F, Soleimani M, Daliri M, Behmanesh M, Mobarra N, Mossahebi-Mohammadi M, et al. MiR-451 up-regulation, induce erythroid differentiation of CD133+cells independent of cytokine cocktails. Iran J Basic Med Sci. 2013; 16 (6): 756-763.

[23] Kohrs N, Kolodziej S, Kuvardina ON, Herglotz J, Yillah J, Herkt S, et al. MiR144 / 451 expression is repressed by RUNX1 during megakaryopoiesis and disturbed by RUNX1 / ETO. PLoS Genet. 2016; 12 (3): e1005946.

[24] Pase L, Layton JE, Kloosterman WP, Carradice D, Waterhouse PM, Lieschke GJ. MiR-451 regulates zebrafish erythroid maturation in vivo via its target gata2. Blood. 2009; 113 (8): 1794-1804.

[25] Wang LS, Li L, Li L, Chu S, Shiang KD, Li M, et al. MicroRNA-486 regulates normal erythropoiesis and enhances growth and modulates drug response in CML progenitors. Blood. 2015; 125 (8): 1302-1313.

[26] Sun Y, Xiao FJ, Zhang YK, Sun HY, Wang H, Wang LS. Dynamic expression of microRNA-486 during erythroid diferentiation of hematopoietic cells. Milit Med. 2013; 37 (4): 263-270. 
[27] Shi XF, Wang H, Kong FX, Xu QQ, Xiao FJ, Yang YF, et al. Exosomal miR-486 regulates hypoxia-induced erythroid differentiation of erythroleukemia cells through targeting Sirt1. Exp Cell Res. 2017; 351 (1): 74-81.5737.

[28] Kosaka N, Sugiura K, Yamamoto Y, Yoshioka Y, Miyazaki H, Komatsu $\mathrm{N}$, et al. Identification of erythropoietin-induced microRNAs in haematopoietic cells during erythroid differentiation. Br J Haematol. 2008; 142 (2): 293-300.

[29] Fabbri E, Manicardi A, Tedeschi T, Sforza S, Bianchi N, Brognara E, et al. Modulation of the biological activity of microRNA-210 with peptide nucleic acids (PNAs). Chem Med Chem. 2011; 6 (12): 2192-2202.

[30] Bianchi N, Zuccato C, Lampronti I, Borgatti M, Gambari R. Expression of miR-210 during erythroid differentiation and induction of $\gamma$-globin gene expression. BMB Rep. 2009; 42 (8): 493-499.

[31] Bavelloni A, Poli A, Fiume R, Blalock W, Matteucci A, Ramazzotti G, et al. PLC-beta 1 regulates the expression of miR-210 during mithramycin-mediated erythroid differentiation in K562 cells. Oncotarget. 2014; 5 (12): 4222-4231.

[32] Sarakul O, Vattanaviboon P, Tanaka Y, Fucharoen S, Abe Y, Svasti S, et al. Enhanced erythroid cell differentiation in hypoxic condition is in part contributed by miR-210. Blood Cells Mol Dis. 2013; 51 (2): 98-103.

[33] Ruan J, Liu XG, Xiong XD, Zhang CL, Li JB, Zheng HL, et al. MiR-107 promotes the erythroid differentiation of leukemia cells via the downregulation of Cacna2d1. Mol Med Rep. 2015; 11 (2): 1334-1339.

[34] Wang GY, Zhao R, Zhao XS, Chen X, Wang D, Jin YJ, et al. MicroRNA-181a enhances the chemotherapeutic sensitivity of chronic myeloid leukemia to imatinib. Oncol Lett. 2015; 10 (5): 2835-2841.

[35] Li YX, Bai H, Zhang ZZ, li WH, Dong L, Wei XJ, et al. The up-Regulation of miR-199b-5p in erythroid differentiation is associated with GATA-1 and NF-E2. Mol Cells. 2014; 37 (3): 213-219.

[36] Ganan-Gomez I, Wei Y, Yang H, Pierce S, Bueso-Ramos C, Calin G, et al. Overexpression of miR-125a in myelodysplastic syndrome CD34+ Cells modulates NF-kB activation and enhances erythroid differentiation arrest. PLoS One. 2014; 9 (4): e93404.

[37] Zhai PF, Wang F, Su R, Lin HS, Jiang CL, Yang GH, et al. The regulatory roles of microRNA-146b-5p and its target platelet-derived growth factor receptor (PDGFRA) in erythropoiesis and megakaryocytopoiesis. J Bio Chem. 2014; 289 (33): 22600-22613.

[38] Kadmon CS, Landers CT, Li HS, Watowich SS, Rodriguez A, King KY. MicroRNA-22 controls interferon alpha production and erythroid maturation in response to infectious stress in mice. Exp Hematol. 2017; 56: 7-15.

[39] Zhu Y, Wang DS, Wang F, Li TT, Dong L, Liu HW, et al. A comprehensive analysis of GATA-1-regulated miRNAs reveals miR-23a to be a positive modulator of erythropoiesis. Nucleic Acids Res. 2013; 41 (7): 4129-4143.

[40] Ma YN, Wang B, Jiang FB, Wang DS, Liu HW, Yan YM, et al. A feedback loop consisting of microRNA 23a / 27a and the $\beta$-like globin suppressors KLF3 and SP1 regulates globin gene expression. Mol Cell Biol. 2013; 33 (20): 3994-4007.
[41] Wang DS, Si S, Wang Q, Luo GC, Du Q, Liang Q, et al. MiR-27a promotes hemin-induced erythroid differentiation of K562 Cells by targeting CDC25B. Cell Physiol Biochem. 2018; 46 (1): 365-374.

[42] Wang F, Zhu Y, Guo LH, Dong L, Liu HW, Yin HX, et al. A regulatory circuit comprising GATA1/2 switch and microRNA-27a / 24 promotes erythropoiesis. Nucleic Acids Res. 2014; 42 (1): 442-457.

[43] Guglielmelli P, Tozzi L, Bogani C, Iacobucci I, Ponziani V, Martinelli G, et al. Overexpression of microRNA-16-2 contributes to the abnormal erythropoiesis in polycythemia vera. Blood. 2011; 117 (25): 6923-6927.

[44] Ward CM, Li B, Pace BS. Stable expression of miR-34a mediates fetal hemoglobin induction in K562 cells. Exp Biol Med. 2016; 241 (7): 719-729.

[45] Li YM, Liu SG, Sun HY, Yang YD, Qi HY, Ding N, et al. MiR-218 inhibits erythroid differentiation and alters iron metabolism by targeting ALAS2 in K562 Cells. Int J Mol Sci. 2015; 16 (12): 28156-28168.

[46] Mittal SPK, Mathai J, Kulkarni AP, Pal JK, Chattopadhyay S. MiR-320a regulates erythroid differentiation through MAR binding protein SMAR1. Int J Biochem Cell Biol. 2013; 45 (11): 2519-2529.

[47] Jiang L, Wang X, Wang Y, Chen X. Quantitative proteomics reveals that miR-222 inhibits erythroid differentiation by targeting BLVRA and CRKL. Cell Biochem Funct. 2018; 36 (2): 95-105.

[48] Ma YN, Chen MT, Wu ZK, Zhao HL, Yu HC, Yu J, et al. Emodin can induce K562 cells to erythroid differentiation and improve the expression of globin genes. Mol Cell Biochem. $2013 ; 382(1-2): 127-136$.

[49] Felli N, Fontana L, Pelosi E, Botta R, Bonci D, Facchiano F, et al. MicroRNAs 221 and 222 inhibit normal erythropoiesis and erythroleukemic cell growth via kit receptor down-modulation. Proc Natl Acad Sci. 2005; 102 (50): 18081-18086.

[50] Lin X, Rice KL, Buzzai M, Hexner E, Costa FF, Kilpivaara O, et al. MiR-433 is aberrantly expressed in myeloproliferative neoplasms and suppresses hematopoietic cell growth and differentiation. Leukemia. 2013; 27 (2): 344-352.

[51] Li YM, Zhang Q, Du ZL, Lu ZC, Liu S, Zhang L, et al. MicroRNA 200a inhibits erythroid differentiation by targeting PDCD4 and THRB. Br J Haematol. 2017; 176 (1): 50-64.

[52] Felli N, Pedini F, Romania P, Biffoni M, Morsilli O, Castelli $\mathrm{G}$, et al. MicroRNA 223-dependent expression of LMO2 regulates normal erythropoiesis. Haematologica. 2009; 94 (4): 479-486.

[53] Yuan JY, Wang F, Yu J, Yang GH, Liu XL, Zhang JW. MicroRNA-223 reversibly regulates erythroid and megakaryocytic differentiation of K562 cells. J Cell Mol Med. 2009; 13 (11-12): 4551-4559.

[54] Sun ZW, Wang Y, Han X, Zhao XL, Peng YL, Li YS, et al. MiR-150 inhibits terminal erythroid proliferation and differentiation. Oncotarget. 2015; 6 (40): 43033-43077.

[55] Zhao HL, Bu WJ, Li YX, Zhai D, Wen X, Yu J. MiR-34a-5p inhibits the erythroid differentiation of K562 cells. Basic Clin Med. 2015; 35 (2): 167-173. 
[56] Wang F, Song W, Zhao HM, Ma YN, Li YX, Zhai D, et al. The RNA-binding protein QKI5 regulates primary miR-124-1 processing via a distal RNA motif during erythropoiesis. Cell Res. 2017; 27 (3): 416-439.

[57] Andolfo I, De Falco L, Asci R, Russo R, Colucci S, Gorrese M, et al. Regulation of divalent metal transporter 1 (DMT) non-IRE isoform by the microRNA Let-7d in erythroid cells. Haematologica. 2010; 95 (8): 1244-1252.

[58] Wang F, Yu J, Yang GH, Wang XS, Zhang JW. Regulation of erythroid differentiation by miR-376a and its targets. Cell Res. 2011; 21 (8): 1196-1209.

[59] Yang GH, Wang F, Yu J, Wang XS, Yuan JY, Zhang JW. MicroRNAs are involved in erythroid differentiation control. $\mathrm{J}$ Cell Biochem. 2009; 107 (3): 548-556.

[60] Huang XQ, Gschweng E, Handel BV, Cheng DH, Mikkola HK, Witte ON. Regulated expression of microRNAs-126/126* inhibits erythropoiesis from human embryonic stem cells. Blood. 2011; 117 (7): 2157-2165.

[61] Zhao HW, Kalota A, Jin SH, Gewirtz AM. The c-MYB proto-oncogene and microRNA-15a comprise an active autoregulatory feedback loop in human hematopoietic cells. Blood. 2009; 113 (3): 505-516.

[62] Kronstein-Wiedemann R, Thiel J, Milanov P, Pasini E, Tonn T. Role of miR-30a-5p and miR-26a-5p in induction of terminal differentiation in human K562 erythroleukemia cells. Cytotherapy. 2020; 22 (5): S191.

[63] Kotaki R, Kawashima M, Yamaguchi A, Suzuki N, Koyama-Nasu R, Ogiya D, et al. Overexpression of miR-669m inhibits erythroblast differentiation. Sci Rep. 2020; 10 (1): 13554.

[64] Zhang YY, Li LP, Yu CJ, Senyuk V, Li FX, Quigley JG, Zhu TY, Qian ZJ. miR-9 upregulation leads to inhibition of erythropoiesis by repressing FoxO3. Sci Rep. 2018; 8 (1): 6519.

[65] Wang Q, Huang Z, Xue HL, Jin CC, Ju XL, Han JD, et al. MicroRNA miR-24 inhibits erythropoiesis by targeting activin type I receptor ALK4. Blood. 2008; 111 (2): 588-595.

[66] Ma YN, Wang B, Gong B, Wang F, Zhao HL, Zhang JW, et al. MiR-24 improves $\beta$-like globin gene expression through targeting Sp1. Chin J Biotech. 2013; 29 (7): 946-954. 